\title{
Juridical Analysis of Integrated Electronic Responsibility Services based on Agricultural \& Spatial Land Regulation
}

\author{
Ferika Rahmatul Zulfa*) and Anis Mashdurohatun $\left.{ }^{* *}\right)$ \\ ${ }^{*}$ Faculty of Law, Universitas Islam Sultan Agung (UNISSULA) Semarang, E-mail: \\ ferikarahmatulzulfa@gmail.com \\ ${ }^{* *}$ Faculty of Law, Universitas Islam Sultan Agung (UNISSULA) Semarang, E-mail: \\ anism@unissula.ac.id
}

\begin{abstract}
HT-el service is a form of service provision from the Ministry of ATR / BPN in facilitating services to the community by taking advantage of developments in information technology. Implementation of Permen No. 9/2019 concerning electronic HT still depends on the readiness of each land office in implementing an electronic system. There are many advantages that are obtained in the online registration feature, but there are also many disadvantages in it. One of the advantages obtained in this online registration is that it can save time for users of the land bureaucracy, of course the main hope is that the effectiveness and efficiency of the bureaucracy can actually be achieved legal system construction and constraints. This study uses an empirical juridical approach. This research analyzes the problems that have been formulated by combining primary, secondary and tertiary legal materials.
\end{abstract}

Keywords: Services; Mortgage; Electronics.

\section{Introduction}

Economic development as part of national development is one of the efforts to realize just and prosperous people's welfare based on Pancasila and the 1945 Constitution of the Republic of Indonesia. In the context of increasing national development that focuses on the economic sector, the actors include: The government as well as the community as individuals and legal entities, very large amounts of funds are needed, so that with the increase in these development activities, the need for funds will also increase, most of which are obtained through credit.

Banking credit is one of the conventional bank businesses that has been widely used by people who need funds in Article 1 point 2 of Act No. 10 of 1998 concerning Banking, a bank is a business entity that collects funds from the public in the form of savings and distributes them to the public in the form of credit and or other forms in order to improve the standard of living of the people at large, the bank also functions as a financial intermediary that aims to support development national development is not individual development, increasing the distribution of the welfare of the people, not the welfare of individuals or groups 
and increasing economic growth and national stability, ${ }^{1} \mathrm{Credit}$ agreements are usually made by the creditor, namely the bank, while the debtor only learns and understands it. However, this credit agreement should really need special attention from both parties because the credit agreement has a very important function in granting, managing and implementing it because of an agreement between the two parties which we can call the debtor and creditor, because if the debtor signs a credit agreement that is considered binding on both parties and applies as law for both. ${ }^{2}$

Given the importance of the position of credit funds in the development process, it is appropriate that the credit giver and recipient as well as other related parties receive protection through a strong guarantee rights institution that can also provide legal certainty for all interested parties. ${ }^{3}$ One of the strong guarantee institutions that can be imposed on land rights which will be discussed in this paper is mortgage rights. Mortgage rights are collateral rights on land for the settlement of certain debts, which give priority to certain creditors over other creditors. In the sense that if the debtor is in default, the creditor holding the mortgage has the right to sell through a public auction the land used as collateral according to the provisions of the relevant legislation, with prior rights over other creditors. ${ }^{4}$

According to Article 1 paragraph 1 of Act No. 4 of 1996 concerning Mortgage on Land and Objects Relating to Land (hereinafter referred to as "UUHT"), Mortgage on land and objects related to land is a guarantee right that levied on land rights as referred to in Act No. 5 of 1960 concerning Agrarian Principles (hereinafter referred to as "UUPA"), whether or not the following other objects are an integral part of the land, for the settlement of certain debts, which provide a position equal to the land rights priority to certain creditors over other creditors. The definition of Mortgage above is not limited to being focused on land alone, but also on other objects that are related or become an integral part of the land. This is different from the provisions in the UUPA, which adheres to the principle of horizontal separation, namely the separation between land and buildings on it ${ }^{5}$ According to Article $4 \mathrm{UUHT}$, the objects of Mortgage Rights are property rights, cultivation rights, building use rights and use rights on State land, which according to applicable provisions must be registered and by their nature can be transferred. The granting of the mortgage is carried out by making the Deed of

\footnotetext{
${ }^{1}$ M. Yahya Harahap, Beberapa Tinjauan Tentang Permasalahan Hukum Buku Kedua , (Bandung : Citra Aditya Bakti, 1997), p. 210

${ }^{2}$ Sutan Remy Sjahdeini, Hak Tanggungan Asas-Asas Ketentuan-Ketentuan Pokok dan Masalah Yang Dihadapi Oleh Perbankan (Suatu Kajian Mengenai Undang-Undang Hak Tanggungan), (Bandung: Alumni, 1999), p. 26

3 Adrian Sutedi, Implikasi Hak Tanggungan Terhadap Pemberian Kredit Oleh Bank dan Penyelesaian Kredit Bermasalah, (Jakarta: BP Cipta Jaya, 2006), p.1

${ }^{4}$ Ibid, p. 3

${ }^{5}$ Boedi Harsono, Hukum Agraria Indonesia Sejarah Pembentukan Undang-Undang Pokok Agraria, Isi dan Pelaksanaannya, Cetakan ke-8, (Jakarta: Djambatan, 1999), p. 19.
} 
Granting Mortgage (hereinafter referred to as "APHT") made by the Land Deed Making Officer (hereinafter referred to as "PPAT") in accordance with the applicable laws and regulations. This Mortgage has the nature of accesoir or a follow-up agreement, meaning that the debt guarantee agreement on the Mortgage does not stand alone because it was previously preceded by the main agreement, namely the debt-receivable agreement. If the principal agreement is deleted or canceled, the accessoir agreement will automatically be deleted as well.

In this case, it is a public official who is given the authority to make authentic deeds regarding certain legal actions regarding, land rights or Ownership Rights to Flat Units, while the PPAT deed is a deed made by PPAT as evidence that certain legal actions have been carried out regarding rights on land or on Ownership of Flats, the PPAT deed is a tool to prove that a legal act has been committed. Therefore, if the legal action is canceled or canceled, then the PPAT deed concerned no longer serves as evidence of the legal action. PPAT is appointed and dismissed by the Minister of Agrarian Affairs to serve the community in making PPAT deeds in certain areas. ${ }^{6}$.

As an authentic deed, in addition to fulfilling the elements of an authentic deed determined by the Civil Code and the Position Act, APHT has characteristics and must meet the requirements as stipulated in the Mortgage Law. The process of imposing mortgage rights based on the Mortgage Law is through two stages, first, the stage of granting Mortgage Rights by making the Deed of Granting Mortgage (APHT) by PPAT before a debt agreement has been made which forms the basis of this Mortgage; second, the registration stage by the land office, this registration is important because it proves the birth of the mortgaged that is charged, after the APHT is made by the interested parties, then within 7 (seven) working days it must be registered with the local Land Office complete with supporting documents. National Land Agency The National Land Agency (BPN) is a state administrative institution whose authority is only to carry out tasks in the field of government, ${ }^{7}$ but recently the Minister of ATR/Head of BPN issued Regulation of the Minister of Agrarian Affairs and Spatial Planning of the Head of the National Land Agency Number 9 of 2019 concerning Electronically Integrated Mortgage Services which came into force as of June 21, 2019 (Permen ATR/KBPN 9 of 2019). The regulation is a continuation of the previous ATR/KBPN Ministerial Regulation, namely Ministerial Regulation No. 3 of 2019 concerning the use of electronic systems and Ministerial Regulation No. 7 of 2019 concerning changes in the form of certificates.

The issuance of these candies is a step forward by the Ministry of Agrarian Affairs and Spatial Planning of the National Land Agency in facilitating the public to obtain services from the ministry by utilizing technological developments. 9 of

\footnotetext{
${ }^{6}$ Hermansyah, Hukum Perbankan Nasional Indonesia, (Jakarta: Prenada Media, 2005), p. 20

${ }^{7}$ Adrian Sutedi, Hukum Hak Tanggungan, (Jakarta: Sinar Grafika, 2012), p. 161.
} 
2019 concerning HT-el still depends on the readiness of each land office in implementing electronic systems in providing services to the community.

There are important points in HT-el related to the duties, functions and authorities of PPAT; there is a separation between the act of registering HT-el with the act of submitting the APHT deed to the Land Office.

If all this time the act of submitting the deed as well as the registration of Mortgage Rights has been assigned to the PPAT, then in the Ministerial Regulation separating it into submission of APHT to the Land Office, it remains the PPAT's duty to submit the deed he made according to the specified time limit, the submission of the deed can be done electronically (Article 10 ) and the application for registration of HT-el becomes the obligation of the creditor, so that if the creditor is negligent in not registering it, the risks and legal consequences make the guarantee provided does not provide the special rights granted by the Mortgage Law. It turns out that besides the regulation in Ministerial Regulation 9/2019 which is quite crucial, namely the registration of HT-el is only possible for HT providers which must be carried out by the debtor himself (Article 9 paragraph (5).

Based on the background of the problems above, the writer is interested in formulating the following problems: 1 ) How is the implementation of Electronically Integrated Mortgage Services based on the Minister of Agrarian Affairs and Spatial Planning Number 9 of 2019 Juncto Number 5 of 2020 in the construction of legal values? 2) What are the impacts arising from changes in the way of registration of Electronic Mortgage Rights in the construction of the legal system? What are the obstacles?

\section{Research Methods}

In this study, the approach used in solving the problem is to use an empirical juridical approach. The juridical approach in question is that law is seen as a norm or das sollen), because in discussing the problem in this study, legal materials are used (both written law and unwritten law or both primary, secondary and tertiary legal materials. While the empirical approach is by looking at the law as a social, cultural or das sein reality because in this study the data used were primary data obtained directly from the research location.

So, the empirical juridical approach intended in this study is that in analyzing the problems that have been formulated, it is done by combining legal materials both primary, secondary and tertiary (which is secondary data) with primary data obtained in the field, namely about PPAT responsibilities in the implementation and implementation of the electronic mortgage registration system.

\section{Results and Discussion}

3.1. Implementation of Electronically Integrated Mortgage Services Based on the Minister of Agrarian Affairs and Spatial Planning Number 9 of 2019 Juncto Number 5 of 2020 in the Construction of Legal Values 
Based on Article 7 paragraph (1) of the Regulation of the Minister of Agrarian Affairs and Spatial Planning/Head of the National Land Agency Number 9 of 2019, those who can use the Electronic Mortgage System service are called Mortgage users are individuals/legal entities as creditors and the Ministry of State Civil Apparatus in charge of serving Rights. Dependents are the Ministry of Agrarian Affairs and Spatial Planning/National Land Agency (Ministry of ATR/BPN). At the beginning, before the Electronic Mortgage Guarantee process is carried out, the user must be registered first with the following conditions:

a. Users of the Electronic Mortgage System service, consisting of individuals/legal entities as creditors and the Ministry of State Civil Apparatus in charge of serving Mortgage Rights;

b. The individual/legal entity as referred to previously must be a Registered User on the Electronic Mortgage System, by fulfilling the following requirements:

1) Have an electronic domicile;

2) Certificate of Registration at OJK;

3) Statement of fulfillment of the requirements and criteria and conditions as a Registered User; and

4) Other conditions determined by the Ministry. The Ministry of Agrarian and Spatial Planning/National Land Agency, which in this case is the Land Office, verifies the registration and has the right to refuse the said registration.

Broadly speaking, the mechanism for guaranteeing Mortgage with the Electronic Mortgage System is as follows:

a. Registered users apply for Mortgage services electronically through the Electronic Mortgage System that has been provided by the Ministry of Agrarian Affairs and Spatial Planning/National Land Agency and complete the application requirements in accordance with the provisions of the legislation;

b. The applicant must make a statement regarding the accountability for the validity and correctness of the submitted Electronic Document data. The following application requirements with the statement letter are made in the form of an Electronic Document.

c. Specifically regarding the requirements in the form of a Certificate of Land Rights or Ownership of Flat Units, it must be in the name of the Debtor;

d. Service requests that have been received by the Electronic Mortgage System will be given a proof of application registration issued by the system. The proof of registration of the said application shall at least contain, among other things, the number of the application registration 
file; date of application registration; applicant's name; and service fee payment code;

e. The application is processed after the application data and application registration fee are confirmed by the electronic system. Based on Article 12 of the Regulation of the Minister of Agrarian Affairs and Spatial Planning/Head of the National Land Agency Number 9 of 2019, Mortgage services are subject to fees in accordance with the provisions of the laws and regulations regarding Non-Tax State Revenue applicable to the Ministry of Agrarian Affairs and Spatial Planning/National Land Agency.

f. After obtaining proof of application registration, the applicant pays the fee through the perception bank no later than 3 (three) days after the date of application registration.

g. The application is processed after the application data and application registration fee are confirmed by the electronic system. In the event that the payment of the registration fee by the applicant is not confirmed by the system, the applicant can confirm directly to the Land Office or the Complaint Service. In the event that the period expires and the Applicant does not make payment, the application is declared void.

h. The issuance of the results of the Mortgage Service is carried out on the 7th (seventh) day after the submission of a confirmed application

i. The Electronic Mortgage System will issue the results of the mortgage service in the form of a Mortgage Certificate; and records of mortgage rights in the land book and Certificate of Land Rights or Ownership Rights on Flat Units.

j. The registration of Mortgage Rights on the Certificate of Land Rights or Property Rights of the Flats can be done by the creditor by printing the records issued by the Electronic Mortgage System and embedding the printed results of the notes on the Certificates of Land Rights or Property Rights of the Flats.

Electronic Documents, Mortgage Certificates issued by the Electronic Mortgage System are given an electronic signature. Electronic Signature is a signature consisting of Electronic Information that is attached, associated or related to other Electronic Information that is used as a means of verification and authentication. Electronic signatures are carried out in accordance with the provisions of laws and regulations, namely the Regulation of the Minister of Agrarian Affairs and Spatial Planning/Head of the National Land Agency Number 3 of 2019 concerning the Application of Electronic Signatures. The electronic signature can be used to give approval and/or ratification of an electronic land document in carrying out the duties and functions of the Ministry.

\subsection{The Impact of the Change in the Method of Electronic Mortgage Registration in the Construction of the Legal System and its Obstacles}


Obstacles in integrated HT registration services electronic:

a. The user of the electronic HT system must be a registered user. The requirements to become an electronic mortgage user are regulated in Article 7 paragraph (3) which includes:

1) Electronic domicile;

2) Certificate of registration at OJK;

3) Statement of fulfillment of the requirements and criteria as well as approval of the provisions as a registered user; and

4) Other conditions determined by the ministry.

In the general provisions of Article 1 point 2 of the Regulation of the Minister of Agrarian Affairs and Spatial Planning/Head of the National Land Agency Number 9 of 2019 it is stated that creditors are parties who owe debts in certain debt relationships. Creditors can be individuals or legal entities. The creditor in the form of an individual in entering into an agreement must be a legally capable person as referred to in Article $1329^{8}$ junto $1330^{9}$ Civil Code. Meanwhile, if the legal subject is a legal entity, then it is not only seen in the person / person because in addition to legal competence, it must also be seen in its authority as regulated in the articles of association which are the rules of the game or the constitution of the legal entity such as for example in a PT legal entity, where based on the provisions of the Articles of Association of the Director/2 (two) Directors are authorized to represent the Board of Directors of the PT, in addition to that the Board of Directors concerned must also be legally competent, and also in carrying out legal actions of course must still pay attention to other provisions of the articles of association such as the approval of other organs of the Company. The PT is the Board of Commissioners or the GMS depending on the legal actions to be carried out by the Board of Directors, such as taking money from the bank or pledging assets.

One of the requirements as a user of this Electronic Mortgage in the Regulation of the Minister of Agrarian Affairs and Spatial Planning/Head of the National Land Agency Number 9 of 2019 is a Certificate Registered with the OJK. Based on the research results, this requirement is a burdensome and hindering condition, because:

a. In Article 9 UUHT it is stated that the Mortgage Holder is an individual or legal entity domiciled as a debtor, thus, the holder of the Mortgage Right

\footnotetext{
${ }^{8}$ Article 1329 Everyone is qualified to make engagements, if he is not declared incompetent by law.

${ }^{9}$ Article 1330 Incompetent to conclude an agreement are: 1 . Minors; 2 . Those who are put under custody; 3 . Women, in matters stipulated by law, and in general all persons to whom the law has prohibited making certain agreements.
} 
is anyone who is authorized to carry out civil actions to provide debt, i.e. either an Indonesian citizen or an individual foreign entities, whether Indonesian legal entities or foreign legal entities.

b. The Financial Services Authority (OJK) is an independent institution and is free from interference from other parties, which has the functions, duties, and authorities of regulation, supervision, inspection and investigation, and has the scope of regulatory and supervisory duties to the Banking Sector, Capital Market Sector, Sector Insurance, Pension Fund Sector, Financing Institution Sector. In this regulation and supervision, OJK issues regulations including the Financial Services Authority Regulation or what is often called POJK. This POJK is aimed at Financial Services Businesses (PUJK) in the form of legal entities and registered and supervised by the OJK such as Commercial Banks, Rural Banks, Securities Companies, Investment Advisors, Custodian Banks, Pension Funds, Insurance Companies, Reinsurance Companies, Financing Institutions, pawn company, and Guarantee Companies, both those that carry out their business activities both conventionally and according to sharia. This POJK is not addressed to individuals or legal entities that are not FSA registered with the OJK, so that the requirement for a Registered Certificate with the Financial Services Authority is a requirement that becomes an obstacle, because if these conditions are fulfilled, then for the community, both individuals and legal entities that are not engaged in the financial industry and not registered with the OJK cannot obtain a Certificate of Registration with the OJK, so they cannot take advantage of the Electronic Mortgage Service. Perhaps one of the goals to be achieved by the formation of the Regulation of the Minister of Agrarian Affairs and Spatial Planning/Head of the National Land Agency Number 9 of 2019,

c. In Article 9 paragraph (5) of the Regulation of the Minister of Agrarian Affairs and Spatial Planning/Head of the National Land Agency Number 9 of 2019 it is stated that the requirement in the form of a certificate of land rights or ownership rights to an apartment unit must be the name of the debtor.

Article 9 paragraph (5) is contrary to UUHT, because with this provision it will hinder credit practices, where in the world of credit, the guarantee given by the debtor is not necessarily in the name of the debtor himself, it can be in the name of the husband or wife, or parents, siblings or grandfathers. , or anyone else including on behalf of a legal entity. Giving guarantees on behalf of other people is not prohibited by law, within the scope of civil law it does not matter who provides guarantees, whether the debtor is himself or a third party, but what is at issue is whether the guarantor is competent and authorized. The involvement of this third party can be interpreted that the 
third party bears the repayment of the credit given to the debtor, as regulated in Article 1820 of the Civil Code, where it is stated that:

"Insurance is an agreement by which a third party, for the benefit of the debtor, binds himself to fulfill the debtor's engagement, when this person himself does not fulfill it".

In UUHT Article 8 it is stated that the Provider of Mortgage is an individual or legal entity who has the authority to take legal actions against the object of the Mortgage concerned. The provisions of Article 8 do not make a problem if the debtor has the right to provide guarantees, here what is emphasized is that the person or legal entity providing the guarantee must be the party authorized to carry out legal actions in this case the provision of Mortgage guarantees, and also considering the provisions in Article 4 UUHT where it is mentioned about the various objects of Mortgage, where in the explanation of Article 4 UUHT it is also not stated that the object of the Mortgage must be owned or registered in whose name, so it can be said that the object of Mortgage can be owned by a third party, whether it is an individual or a legal entity. The subject and object of the Mortgage Rights in UUHT provides broad limits on land ownership that can be guaranteed and it is possible that the subject of the Mortgage Rights or the Mortgage Giver is a third party and the object of the Mortgage is land under the ownership of a third party, most importantly the Mortgage Giver is competent and has the authority at the time the Mortgage agreement is made.

d. In the Regulation of the Minister of Agrarian Affairs and Spatial Planning/Head of the National Land Agency Number 9 of 2019 it is not regulated regarding the mechanism for registering Mortgage Rights where creditors consist of several creditors who are credit syndicates. In the Regulation of the Minister of Agrarian Affairs and Spatial Planning/Head of the National Land Agency Number 9 of 2019 it is not regulated regarding creditors in terms of credit syndication, where in the case of credit syndication, land title certificates generally include the names of these creditors on the Mortgage Certificate.

The application for registration of Mortgage Rights electronically becomes the obligation of the creditor. In the Regulation of the Minister of Agrarian Affairs and Spatial Planning/Head of the National Land Agency Number 9 of 2019, the obligation to apply for electronic Mortgage registration is the responsibility of the creditor, while in Article 13 paragraph (2) UUHT it is determined: No later than 7 (seven) working days after the signing of the Deed Granting Mortgage as referred to in Article 10 paragraph (2), PPAT is obliged to send the Deed of Granting 
Mortgage concerned and other required documents to the Land Office. And if the creditor is negligent in his registration/does not register it.

\section{Closing}

1) The Electronic Mortgage Registration mechanism is a digital or electronicbased breakthrough service launched by the Ministry of Agrarian Affairs and Spatial Planning/National Land Agency to facilitate land management based on the principles of openness, timeliness, speed, convenience and affordability in the context of public services, as well as to adjust development of law, information technology so that the Mortgage service procedure becomes more effective and efficient. 2) Constraints of electronically integrated HT registration services: a. The user of the electronic HT system must be a registered user in order to become an electronic mortgage user; b. In Article 9 paragraph (5) of the Regulation of the Minister of Agrarian Affairs and Spatial Planning/Head of the National Land Agency Number 9 of 2019 it is stated that the requirements in the form of a certificate of land rights or ownership rights to an apartment unit must be the name of the debtor; $c$. In the Regulation of the Minister of Agrarian Affairs and Spatial Planning/Head of the National Land Agency Number 9 of 2019 it is not regulated regarding the mechanism for registering Mortgage Rights where creditors consist of several creditors who are credit syndicates. 3) The application for registration of Mortgage Rights electronically becomes the obligation of the creditor. In the Regulation of the Minister of Agrarian Affairs and Spatial Planning/Head of the National Land Agency Number 9 of 2019.

\section{References}

Books:

[1] Adrian Sutedi, Hukum Hak Tanggungan, (Jakarta: Sinar Grafika, 2012)

[2] Adrian Sutedi, Implikasi Hak Tanggungan Terhadap Pemberian Kredit Oleh Bank dan Penyelesaian Kredit Bermasalah, (Jakarta: BP Cipta Jaya, 2006)

[3] Boedi Harsono, Hukum Agraria Indonesia Sejarah Pembentukan UndangUndang Pokok Agraria, Isi dan Pelaksanaannya, Cetakan ke-8, (Jakarta: Djambatan, 1999)

[4] Hermansyah, Hukum Perbankan Nasional Indonesia, (Jakarta: Prenada Media, 2005)

[5] M. Yahya Harahap, Beberapa Tinjauan Tentang Permasalahan Hukum Buku Kedua, (Bandung: Citra Aditya Bakti, 1997)

[6] Sutan Remy Sjahdeini, Hak Tanggungan Asas-Asas Ketentuan-Ketentuan Pokok dan Masalah Yang Dihadapi Oleh Perbankan (Suatu Kajian Mengenai Undang-Undang Hak Tanggungan), (Bandung: Alumni, 1999) 